Accra, Ghana', by Dennis McElrath; 'Bureaucracy and Urban Symbol Systems', by Lionel Tiger; ' Groups in Ibadan', by George Jenkins; 'The Political Structure of Urban Centered African Communities', by William Hanna (Co-Author, Judith Hanna); 'Kampala-Mengo', by Aidan Southall; 'Migrancy and Urbanization in a Central African Town [Gwelo]', by William Schwab; 'Structural Discontinuities in African Towns: Some Aspects of Racial Pluralism', by Leo Kuper.

The conference was organized by Horace Miner, who is preparing the papers and results of the sessions for publication.

\title{
Conference at Berkeley on Changing Institutions in Africa
}

A Conference was held at Berkeley on 1 $^{-19}$ June on Changing Institutions in Africa: Theory and Application. The conference was sponsored by the Institute of International Studies, University of California, Berkeley, and was convened by Ethel Albert and David Brokensha of the Committee for African Studies. Participants, who came from many disciplines, presented the following papers:

Thayer Scudder (California Institute of Technology). Social Anthropology and Rural

Development: The Need for New Types of Research and Rapid Survey Techniques.

David Brokensha (UC, Berkeley). Applied Anthroplogy in Anglophone Africa, 1953-64.

Aidan Southall (Syracuse). Urbanization in East Africa: A Case Study.

Edgar Winans (UC, Riverside). Ecology and African Ethnology.

Ethel M. Albert (UC, Berkeley). Traditional Values and Culture Change.

Leslie J. Rubin (Howard). Ghana 1957-64: A Study in Constitutional Change.

Philip J. Foster (Chicago). Problems of Primary and Secondary Education in Africa.

Lincoln R. Page (US Geological Survey). Economic Development and the Earth Sciences.

John M. Letiche (UC, Berkeley). The New Role of Banking and International Trade in African Economic Development.

Dorothea Leighton (Cornell). Definite Mild Psychiatric Disorder: An Index of Social Stress Points.

Robert P. Armstrong (Northwestern). Publishing in Nigeria: A Cultural View.

This was the second interdisciplinary conference organized by the Committee for African Studies at Berkeley. The first conference, held in June 1964, was on the theme of 'Ecology and Economic Development in Africa'; the participants came from both the natural and the social sciences. It is hoped that the papers of both conferences will shortly be published.

\section{The West African Linguistic Society}

THE West African Linguistic Society came into being at the Fifth Congress of West African Languages, held in the University of Ghana between $s$ and 10 April 1965 . At the founding meeting on 9 April a Constitution for the Society was formally agreed and a Council elected.

The Aims of the Society, as stated in Article 2 of the Constitution, are as follows:

(i) to offer membership to and ensure permanent contact among all who are engaged in the scholarly study of the languages of West Africa, their literatures, and any other linguistic aspects of the area;

(ii) to initiate, encourage, and support scholarly research in this field, both for scientific purposes and to assist African nations with the linguistic aspects of their educational and social development;

(iii) to organize such regular meetings, conferences, or congresses as may be thought desirable from time to time, and at least once a year if possible; 